\title{
SHetA2 interference with mortalin binding to p66shc and p53 identified using drug-conjugated magnetic microspheres
}

\author{
Doris Mangiaracina Benbrook • Baskar Nammalwar • \\ Andrew Long • Hiroyuki Matsumoto • Anil Singh • \\ Richard A. Bunce $\cdot$ K. Darrell Berlin
}

Received: 9 September 2013 / Accepted: 9 October 2013 /Published online: 20 November 2013

(C) The Author(s) 2013. This article is published with open access at Springerlink.com

Summary SHetA2 is a small molecule flexible heteroarotinoid (Flex-Het) with promising cancer prevention and therapeutic activity. Extensive preclinical testing documented lack of SHetA2 toxicity at doses 25 to 150 fold above effective doses. Knowledge of the SHetA2 molecular target(s) that mediate(s) the mechanism of SHetA2 action is critical to appropriate design of clinical trials and improved analogs. The aim of this study was to develop a method to identify SHetA2 binding proteins in cancer cells. A known metabolite of SHetA2 that has a hydroxyl group available for attachment was synthesized and conjugated to a linker for attachment to a magnetic microsphere. SHetA2-conjugated magnetic microspheres and unconjugated magnetic microspheres were separately incubated with aliquots of a whole cell protein extract from the A2780 human ovarian cancer cell line. After washing away non-specifically bound proteins with the protein extraction buffer, SHetA2binding proteins were eluted with an excess of free SHetA2. In two independent experiments, an SDS gel band of about $72 \mathrm{kDa}$ was present at differential levels in wells of eluent from SHetA2-microspheres in comparison to wells of eluent

Electronic supplementary material The online version of this article (doi:10.1007/s10637-013-0041-x) contains supplementary material, which is available to authorized users.

D. M. Benbrook $(\bowtie)$

Department of Obstetrics and Gynecology, University of Oklahoma

Health Sciences Center, 975 NE 10th Street, Room 1372, Oklahoma

City, OK, USA

e-mail: doris-benbrook@ouhsc.edu

D. M. Benbrook $\cdot$ A. Long $\cdot$ H. Matsumoto $\cdot$ A. Singh Department of Biochemistry and Molecular Biology, University of Oklahoma Health Sciences Center, 940 Stanton L. Young Blvd., BMSB853, Oklahoma City, OK 73104, USA

B. Nammalwar $\cdot$ R. A. Bunce $\cdot$ K. D. Berlin

Department of Chemistry, Oklahoma State University, Physical

Sciences Building, Stillwater, OK 74078, USA from unconjugated microspheres. Mass spectrometry analysis of the bands (QStar) and straight eluents (Orbitrap) identified mortalin (HSPA9) to be present in the eluent from SHetA2microspheres and not in eluent from unconjugated microspheres. Co-immunoprecipitation experiments demonstrated that SHetA2 interfered with mortalin binding to p53 and p66 Src homologous-collagen homologue (p66shc) inside cancer cells. Mortalin and SHetA2 conflictingly regulate the same molecules involved in mitochondria-mediated intrinsic apoptosis. The results validate the power of this protocol for revealing drug targets.

Keywords Mortalin $\cdot$ HSPA9 $\cdot$ Heteroarotinoids $\cdot$ Ovarian cancer $\cdot$ p66shc $\cdot$ p 53
Abbreviations
CHOP CAAT/enhancer binding protein homologous protein
FBS fetal bovine serum
Flex-Het flexible heteroarotinoid
FOXO3A forkhead box O3A
FT-MS Fourier transform mass spectrometry
HSPA heat shock protein A
IR infrared
MIPS monoisotopic precursor selection
$\mathrm{NF}-\mathrm{kB}$ nuclear factor- $\mathrm{kB}$
NMR nuclear magnetic resonance
NOAEL no observed adverse effect level
p66shc p66 Src homologous-collagen homologue
PTLC preparative thin layer chromatography
PVDS polyvinylidene difluoride
SAR structure activity relationship
SDS sodium dodecyl sulfate-polyacrylamide
SHetA2 sulfur heteroarotinoid A2
STAT3 signal transducer and activator of transcription 3 
TLC thin layer chromatograpy

UV-vis ultraviolet-visible

\section{Introduction}

Advancement of investigational new drugs to clinical trials requires detailed knowledge of the pharmacokinetics, metabolism and toxicity to document that the compound has sufficient pharmaceutical qualities for clinical application. Knowledge of the mechanism can be used to select the appropriate patient population and to design improved analogs. Pre-clinical testing for our lead compound, a flexible heteroarotinoid (Flex-Het) called Sulfur Het A2 (SHetA2, NSC721689) demonstrated reasonable pharmacokinetics and lack of mutagenicity, carcinogenicity, teratogenicity and toxicity [1-5]. SHetA2 has a wide therapeutic window as indicated by the No Observed Adverse Effect Level (NOAEL) of $>1,500 \mathrm{mg} / \mathrm{kg} /$ day identified in the 28 day dog toxicity model in comparison to the ability of 10 to $60 \mathrm{mg} / \mathrm{kg} /$ day to inhibit xenograft tumor growth [5-8]. This lack of in vivo toxicity, along with oral bioavailability and documented inhibition of colorectal tumorigenesis in the $A P C^{\mathrm{min} /+}$ mouse model at $30 \mathrm{mg} / \mathrm{kg}$ given 5 days per week, make SHetA2 an ideal candidate for a cancer prevention drug [9]. SHetA2 sensitization of resistant cells to death receptor activating ligands offers promise for advancement of SHetA2 toward clinical trials as combination therapy with death receptor activating antibodies that are currently in clinical trials $[10,11]$. Mechanistic studies identified that SHetA2 induces G1 cell cycle arrest through reduction of cyclin D1; induces intrinsic apoptosis through direct effects on mitochondria associated with reduction of Bcl-2; enhances death receptor activation of the extrinsic apoptosis pathway through repression of nuclear factor $\mathrm{kB}(\mathrm{NF}-\mathrm{kB})$ and upregulation of the CAAT/ enhancer binding protein homologous protein (CHOP) transcription factor; and induces autophagy and endoplasmic reticulum stress, however the direct mediators of these events remain to be elucidated [7, 12-14].

The mechanism of SHetA2 is independent of the nuclear retinoid receptors and retinoid toxicities, despite the emergence of this compound from a series of structure activity relationship (SAR) studies of retinoic acid receptor-active Hets $[3,6,15,16]$. SHetA2 was derived from a Het backbone that was shown to have 1000 -fold decreased in vivo toxicity in comparison to the parent arotinoid structure while retaining the ability to induce retinoid biological effects $[6,17]$. The increased flexibility of the Flex-Hets was conferred by substituting the more-rigid two-atom linker with a moreflexible, three-atom urea or thiourea linker [16]. The FlexHets differ from the more conformationally-restricted heteroarotinoids in that they act independently of the retinoic acid receptors and are potent inducers of apoptosis in cancer cells while not harming normal cells $[3,7,10,13,16,18]$. The potent and differential apoptosis-inducing activity and lack of retinoid and other toxicities of SHetA2 offer a dramatic improvement in the therapeutic ratio over receptor active Hets. The purpose of this project was to identify SHetA2-binding proteins that may be responsible for mediating the mechanism by which SHetA2 kills ovarian cancer cells.

A variety of approaches have been used for target identification including direct biochemical methods, genetic interactions, and computational inference. Mass spectrometry analysis of drug binding proteins isolated by affinity chromatography is currently the most powerful and frequently-used technology; however, a generic workflow for this procedure has not been established due to the wide variation in the types of drugs and the affinity and expression levels of their targets [19]. The primary limitation of affinity chromatography is the need to derivatize the drug in order to attach it to a scaffold, because the derivative has high risk for losing the bioactivity of the parent compound [20]. Linkers between the drug and scaffold may be needed to avoid interference of the scaffold with protein binding to the attached drug. In this study, a known metabolite of SHetA2 was synthesized, which permitted attachment to a linker designed in such a way that allowed conjugation to a magnetic microsphere with a physical separation between the drug and microsphere. Identification of a SHetA2-binding protein using this affinity chromatography approach was validated by identification of the same protein in two types of mass spectrometry analyses and demonstration that treatment of cells with SHetA2 interferes with target protein binding to client proteins.

\section{Materials and methods}

\section{Chemistry}

In order to attach compound SHetA2 [1] to a solid support while retaining the majority of the structure intact for protein binding, the known metabolite $\mathbf{2}$, which has a hydroxyl group available for attachment, was synthesized as described [21] (Structures of $\mathbf{1}$ and $\mathbf{2}$ are shown in Fig. 1). The SHetA2 metabolite 2 was then further modified as shown in Fig. 1. Amino-dPEG 4 acid was purchased from Quanta Biodesign Limited, Powell, OH 43065, and used as received. Tetrahydrofuran was dried over potassium hydroxide pellets and distilled from lithium aluminium hydride prior to use. Dichloromethane was used from a freshly opened bottle. All reactions were run under dry nitrogen in oven-dried glassware. The reaction was monitored by thin layer chromatography (TLC) on silica gel GF plates (Analtech No 21521). Purification was performed using preparative thin layer chromatography (PTLC) on a $20-\mathrm{cm} \times 20-\mathrm{cm}$ silica gel GF plate (Analtech No 02015). Band elution for both methods was 
Fig. 1 Synthesis scheme for SHetA2 conjugated magnetic microspheres<smiles>CC1(C)CC(C)(C)c2cc(NC(=S)Nc3ccc([N+](=O)[O-])cc3)ccc2S1</smiles>

[1] SHetA2<smiles>CC1(C)CC(C)(CO)c2cc(NC(=S)Nc3ccc([N+](=O)[O-])cc3)ccc2S1</smiles>

[2] SHetA2 Metabolite<smiles>O=C(Cl)Oc1ccc([N+](=O)[O-])cc1</smiles><smiles>CC1(C)CC(C)(COC(=O)Oc2ccc([N+](=O)[O-])cc2)c2cc(NC(=S)Nc3ccc([N+](=O)[O-])cc3)ccc2S1</smiles>

3

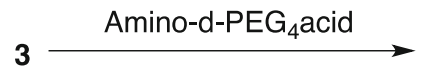<smiles>CC1(C)CC(C)(COC(=O)NCCOCCCOCCC(=O)O)c2cc(NC(=S)Nc3ccc([N+](=O)[O-])cc3)ccc2S1</smiles>

4<smiles>CC1(C)C[C@H](S(=O)(=O)O[Na])C(=O)N1</smiles>

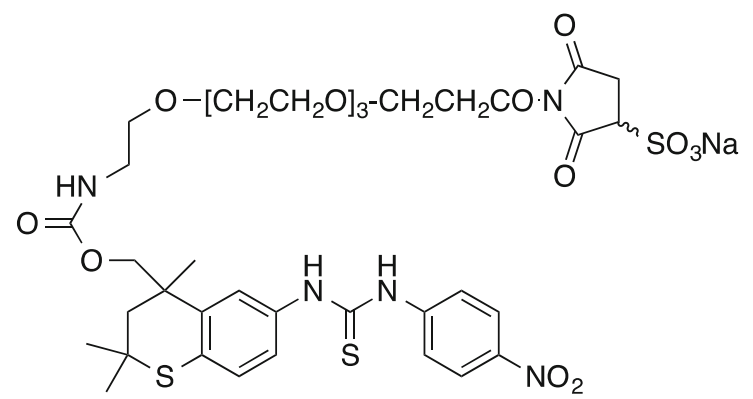

5

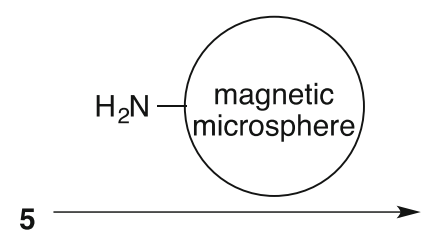<smiles>CC1(C)CC(C)(COC(=O)NCCOCC[SiH3])c2cc(NC(=S)Nc3ccc([N+](=O)[O-])cc3)ccc2S1</smiles>

monitored using a hand-held UV lamp. The infrared (IR) spectrum was run as a thin film on sodium chloride disks. ${ }^{1} \mathrm{H}$ and ${ }^{13} \mathrm{C}$ nuclear magnetic resonance (NMR) spectra were measured in deuteriochloroform at $300 \mathrm{MHz}$ and $75 \mathrm{MHz}$, respectively, and were referenced to internal tetramethylsilane; coupling constants $(\mathrm{J})$ were reported in Hz. The ultravioletvisible (UV-vis) spectrum was collected for the sample using a Varian Cary 5000 spectrophotometer. The mass spectrum was collected for the sample using a Shimadzu LC-MS instrument. 
A 25-mL, three-necked, round-bottomed flask, equipped with a reflux condenser and a magnetic stirrer was charged with $100 \mathrm{mg}(0.24 \mathrm{mmol})$ of metabolite 2 and $5 \mathrm{~mL}$ of tetrahydrofuran. The solution was cooled to $-40{ }^{\circ} \mathrm{C}, 29 \mathrm{mg}$ $(0.24 \mathrm{mmol})$ of 4 -(dimethylamino)pyridine was added. The mixture was stirred for $5 \mathrm{~min}$ to dissolve the solid. To the resulting yellow solution was added dropwise a solution of $48 \mathrm{mg}(0.239 \mathrm{mmol})$ of 4-nitrophenyl chloroformate in $1 \mathrm{~mL}$ of tetrahydrofuran, and the reaction mixture was allowed to stir for $30 \mathrm{~min}$. At this time, TLC eluted with ether:hexane (4:1) confirmed that the reaction was complete (and formed 3).

A solution of exactly $63 \mathrm{mg}(0.24 \mathrm{mmol})$ of amino-dPEG 4 -acid in $3 \mathrm{~mL}$ of dichloromethane was carefully added to the above reaction mixture containing 3 at $-40{ }^{\circ} \mathrm{C}$ over a period of $10 \mathrm{~min}$. The reaction mixture was then slowly allowed to warm to room temperature over a period of $1 \mathrm{~h}$. The reaction mixture then was stirred for $20 \mathrm{~min}$, and concentrated under vacuum. Purification was achieved by PTLC eluted with 98:2 chloroform:methanol. After one elution, the product was washed from the silica gel using ethyl acetate followed by chloroform:methanol (95:5) to give $33 \mathrm{mg}(20 \%)$ of conjugate 4 as a pale yellow liquid. LCMS: $(\mathrm{M}+) 732(\mathrm{Na}+$ adduct), 418; IR: $3375,1740,1640,1592,1515,1475,1335$, $1110 \mathrm{~cm}^{-1}$; ${ }^{1} \mathrm{H}$ NMR: 8.94 (s, $\left.1 \mathrm{H}\right), 8.76(\mathrm{~s}, 1 \mathrm{H}), 8.19$ (d, $J=9.0 \mathrm{~Hz}, 2 \mathrm{H}$ ), 7.85 (obscured m, $1 \mathrm{H}$ ), 7.84 (d, $J=9.0 \mathrm{~Hz}$, $2 \mathrm{H}), 7.45(\mathrm{~s}, 1 \mathrm{H}), 7.13(\mathrm{~d}, J=8.2 \mathrm{~Hz}, 1 \mathrm{H}), 5.46$ (brt, $J=\mathrm{ca}$ $6.2 \mathrm{~Hz}, 1 \mathrm{H}), 4.53$ and $4.42(2 \mathrm{AB}$ patterns, $J=11.0 \mathrm{~Hz}, 1 \mathrm{H})$, $3.76(\mathrm{t}, J=5.5 \mathrm{~Hz}, 2 \mathrm{H}), 3.63(\mathrm{~m}, 13 \mathrm{H}), 3.40(\mathrm{~m}, 2 \mathrm{H}), 3.22$ (m, $2 \mathrm{H}), 2.60$ (t, $J=5.5 \mathrm{~Hz}, 2 \mathrm{H}), 2.36(\mathrm{~d}, J=14.2 \mathrm{~Hz}, 1 \mathrm{H})$, $1.83(\mathrm{~d}, J=14.2 \mathrm{~Hz}, 1 \mathrm{H}), 1.43(\mathrm{~s}, 6 \mathrm{H}), 1.40(\mathrm{~s}, 3 \mathrm{H})$; UV-vis $\left(\mathrm{H}_{3} \mathrm{COH}\right): \max =285 \mathrm{~nm}(\varepsilon=1752)$ and $335 \mathrm{~nm}(\varepsilon=1456)$. The ${ }^{13} \mathrm{C}$ NMR experiment could not be carried out due to the instability of the product. The product decomposed rapidly at $20^{\circ} \mathrm{C}$. Thus, the polyether was attached to the microspheres without further purification.
Only a small quantity of conjugate $\mathbf{4}$ was obtained, and it was transferred in dry ice to SoluLink (San Diego, CA). Compound $\mathbf{4}$ was converted to compound $\mathbf{5}$ by a proprietary method of SoluLink who provided a mass spectrum of the compound as MW - Na+984, the primary $\mathrm{m} / \mathrm{z}$ occurring at 884.20. Compound 5 was reacted with the magnetic microspheres through an amide linkage. This led to conjugate $\mathbf{6}$ attached to the NanoLink Amino-Magnetic Microspheres which were utilized to identify SHetA2 binding proteins.

\section{Isolation of SHetA2 binding proteins}

Protein extracts of the A2780 human ovarian cancer cell line grown to $90 \%$ confluency in $10 \mathrm{~cm}$ plates were isolated using m-PER-PPI (m-PER solution [Thermo Scientific] containing a protease inhibitor cocktail [Active Motif] and a phosphatase inhibitor cocktail [Active Motif]) and stored at $-80{ }^{\circ} \mathrm{C}$ until use. The protein concentration of the extracts was measured with the BCA Protein Assay (Thermo Scientific). SHetA2conjugated NanoLink Amino-Magnetic Microspheres 6 were pelleted with a magnet for $2 \mathrm{~min}$, and the supernatant was removed. The pellet was washed once in $100 \mu \mathrm{L}$ PBS and re-suspended in $100 \mu \mathrm{L}$ of m-PERPPI. Unconjugated NanoLink Amino-Magnetic Microspheres were manipulated under the same conditions in parallel as a negative control. The general experimental procedure is as follows with specific modifications detailed in the subsequent paragraphs and Table 1. Equal volumes of the SHetA2- and unconjugated-microsphere suspensions were pelleted and re-suspended in A2780 protein extract and incubated. The microspheres were pelleted with a magnet and washed one to three times with m-PER-PPI at a volume equal to the incubation volume. Bound proteins were then eluted with excess free SHetA2 in m-PER-PPI, followed by removal of the

Table 1 Experimental Variables Used in Optimization

\begin{tabular}{|c|c|c|c|c|c|c|}
\hline & Protein/SHetA2 ratio & Protein/Beads Ratio & Incubation Conditions & $\mathrm{W}$ & Eluent Conditions & Result \\
\hline 1 & $\begin{array}{l}1360: 1 \\
6.8 \mathrm{mg}: 5 \mu \mathrm{g}\end{array}$ & $\begin{array}{l}1: 1 \\
100 \mu L: 100 \mu L\end{array}$ & rt, $30 \mathrm{~min}$ & 3 & $\begin{array}{l}10 \mu \mathrm{M} \text { SHetA2 } \\
\mathrm{rt}, 10 \mathrm{~min}\end{array}$ & No differential bands \\
\hline 2 & $\begin{array}{l}720: 1 \\
1.8 \mathrm{mg}: 2.5 \mu \mathrm{g}\end{array}$ & $\begin{array}{l}1: 1 \\
50 \mu \mathrm{L}: 50 \mu \mathrm{L}\end{array}$ & $37^{\circ} \mathrm{C}, 30 \mathrm{~min} \rightarrow \mathrm{rt}, 5 \mathrm{~min}$ & 1 & $\begin{array}{l}1 \mathrm{mM} \mathrm{SHetA} 2 \\
37^{\circ} \mathrm{C}, 30 \mathrm{~min}\end{array}$ & $72 \mathrm{kDa}$ specific band ${ }^{\mathrm{a}}$ \\
\hline 3 & $\begin{array}{l}\text { 104:1 } \\
2.6 \mathrm{mg}: 25 \mu \mathrm{g}\end{array}$ & $\begin{array}{l}1: 100 \\
50 \mu \mathrm{L}: 500 \mu \mathrm{L}\end{array}$ & $37^{\circ} \mathrm{C}, \mathrm{rt}, 30 \mathrm{~min} \rightarrow \mathrm{rt}, 5 \mathrm{~min}$ & 1 & $\begin{array}{l}1 \mathrm{mM} \text { SHetA2 } \\
\mathrm{rt}, 30 \mathrm{~min}\end{array}$ & No Differential bands \\
\hline 4 & $\begin{array}{l}72.7: 1 \\
10 \mathrm{mg}: 13.75 \mu \mathrm{g}\end{array}$ & $\begin{array}{l}1: 1.375 \\
200 \mu \mathrm{L}: 275 \mu \mathrm{L}\end{array}$ & rt, $5 \mathrm{~min} \rightarrow 37^{\circ} \mathrm{C}, 25 \mathrm{~min}$ & 2 & $\begin{array}{l}1 \text { mM SHetA2 } \\
37^{\circ} \mathrm{C}, 30 \mathrm{~min}\end{array}$ & Differential 72 kDa band ${ }^{b}$ \\
\hline
\end{tabular}

\footnotetext{
${ }^{a}$ Proteins in silver stain-detected band could not be detected with Coomassie Blue or QStar, but proteins in free eluent could be detected with Orbitrap

${ }^{\mathrm{b}}$ Band and eluent were successfully evaluated by Mass Spec using QStar and Orbitrap, respectively. Specific band was present at a higher level than the non-specific band in Coomassie stained SDS-gel

$W=$ Number of washes, Beads $=$ Microspheres

Bolded rows were used in Mass Spectrometry Analyses
} 
microspheres with a magnet. Aliquots of the washes and eluents of the SHetA2- and unconjugated microspheres were electrophoresed into 2-D SDS-PAGE gels. Four repeats of the experiment were performed in efforts to optimize differential bands observed in the SDS gel wells corresponding to SHetA2-microspheres in comparison to unconjugated microspheres.

In experiment $1,100 \mu \mathrm{L}$ of $\mathrm{A} 2780$ protein extract $(6.8 \mathrm{mg}$ total) was mixed with a volume of $100 \mu \mathrm{L}$ of SHetA2 microspheres (containing approximately $5 \mu \mathrm{g}$ or $12.45 \mathrm{nM}$ SHetA2) from the starting solution and incubated at room temperature in the dark with agitation for $30 \mathrm{~min}$. After 3 washes, bound proteins were eluted by incubating the microspheres in $10 \mu M$ SHetA2 for 10 min with agitation in the dark. Differential bands in the lanes corresponding to SHetA2 eluents from the SHetA2- and unconjugated microspheres could not be visualized upon staining the SDS-PAGE gel with Coomassie Blue.

Experiment 2 was designed to reduce the non-specific binding in SDS-gel bands corresponding to unconjugated microspheres by decreasing the amount of protein added and to increase the specific binding in SDS-gel bands corresponding to SHetA2-microspheres by increasing the incubation temperature. Because a limited amount of microspheres was available, both parameters were altered simultaneously. In experiment 2, $50 \mu \mathrm{L}$ of $\mathrm{A} 2780$ protein extract $(1.8 \mathrm{mg}$ ) was incubated with the SHetA2- or unconjugated magnetic microspheres at $37^{\circ} \mathrm{C}$ for $30 \mathrm{~min}$ in the dark without agitation, followed by $5 \mathrm{~min}$ of slow agitation at room temperature in the dark. After one wash, bound proteins were eluted by incubating the microspheres with $1 \mathrm{~m} M$ SHetA2 in $20 \mu \mathrm{L}$ of m-PERPPI for $30 \mathrm{~min}$ at $37{ }^{\circ} \mathrm{C}$ in the dark. Again no differential bands were observed between the lanes corresponding to the SHetA2- and unconjugated microspheres eluents when the gel was stained with Coomassi blue; however, a differential band was observed upon staining of a repeat gel with the Plus One DNA Silver Staining Kit (Amersham Biosciences) (Fig. 2a).

Experiment 3 was designed to increase the yield of this specific band to levels that could be evaluated by mass spectrometry. Based on the presumption that the SHetA2 attached to the microspheres was the limiting factor, the ratio of protein to microspheres was altered to $1: 100$ by using a volume of $50 \mu \mathrm{L}$ of A2780 protein extract containing $2.6 \mathrm{mg}$ of protein and incubating with $500 \mu \mathrm{L}$ of unconjugated microspheres or SHetA2-microspheres (25 $\mu \mathrm{g}$ or $62.25 \mathrm{n} M$ SHetA2). The extract was incubated and eluted as described for experiment 2; however, the levels of proteins present in the SDS-PAGE gel lanes corresponding to SHetA2- and unconjugated microspheres were too filled with non-specific binding proteins to reveal a differential band.

Experiment 4 was designed to increase the yield by increasing the amount of protein added and to reduce the nonspecific background binding by increasing the number of washes. Thus, $275 \mu \mathrm{L}$ of SHetA2-microspheres $(13.75 \mu \mathrm{g}$ or $34.24 \mathrm{n} M$ SHetA2) or unconjugated-microspheres were mixed with $200 \mu \mathrm{L}$ of A2780 protein extract (approximately
Fig. 2 SDS Gels. a Silverstained SDS-gel of aliquots of the indicated washes and eluents from experiment 2. b Coomassie Blue-stained SDS-gel of SDS-G of aliquots of the indicated washes and eluents from experiment 4 . The arrow indicates the location in the dried gel where bands were excised from the last two lanes for QStar Mass Spectrometry Analysis. Beads $=$ Microspheres

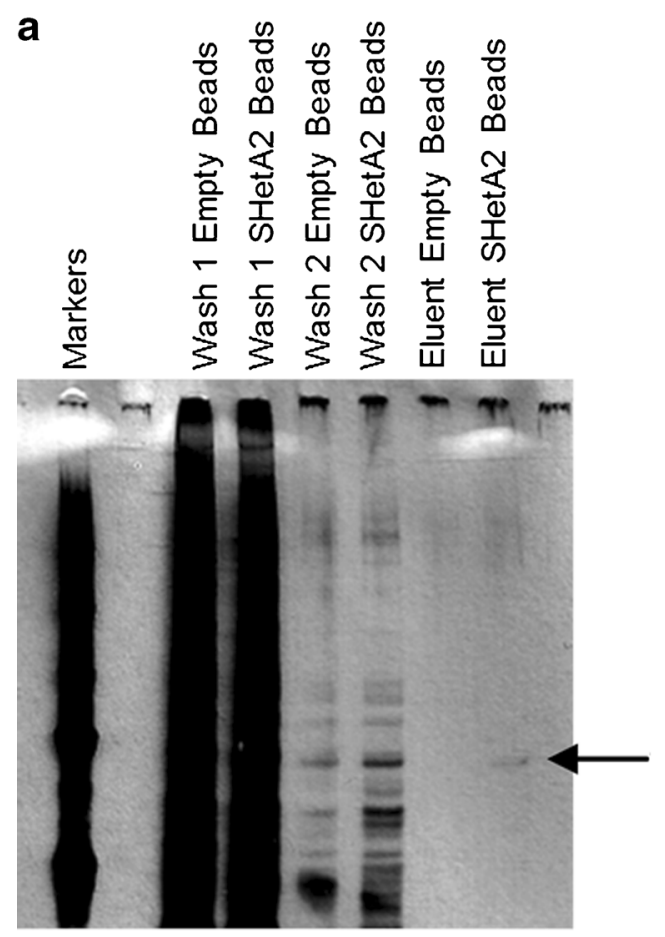

Experiment 2 b

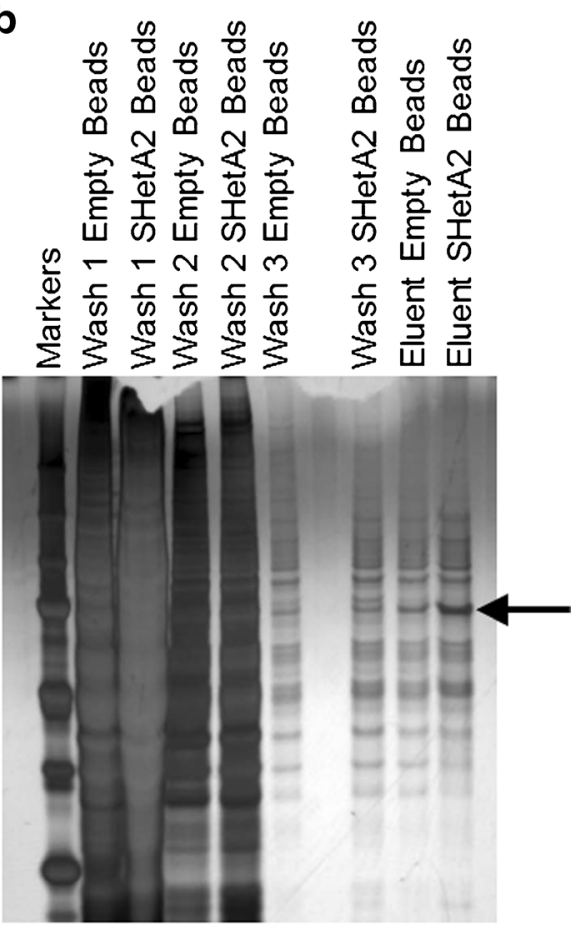

Experiment 4 
$10 \mu \mathrm{g}$ ), agitated for $5 \mathrm{~min}$ in the dark at room temperature and then incubated without agitation at $37{ }^{\circ} \mathrm{C}$ for $25 \mathrm{~min}$ in the dark. Two washes with $300 \mu \mathrm{L}$ of m-PER-PPI were performed, followed by an elution step with $30 \mu \mathrm{L}$ of $1 \mathrm{mM}$ SHetA 2 in m-PER-PPI for $5 \mathrm{~min}$ at $37^{\circ} \mathrm{C}$. A differential band was discerned between the lanes corresponding to the SHetA2- and unconjugated microspheres upon Coomassie blue staining of the SDS-PAGE gel; however, the nonspecific binding was very high (Fig. $2 b$ ).

Efforts to regenerate and re-use the SHetA2-microspheres were unsuccessful. The specific bands in experiments 2 and 4 were evaluated by QStar Mass spectrometry and frozen aliquots of the eluents were thawed and evaluated by Orbitrap Mass spectrometry.

Mass spectrometry analysis of bands excised from SDS-PAGE gels

Identification of proteins that bind to the SHetA2 affinity resin was determined by a standard proteomics analysis as briefly described below. The protein bands were excised and cut into small pieces and destained with $5 \mathrm{mM}$ sodium thiosulfate/ $15 \mathrm{~m} M$ potassium ferricyanide in water. After rinsing with $25 \mathrm{~m} M$ ammonium bicarbonate in $50 \%$ acetonitrile, the proteins in the gel were reduced in $55 \mathrm{mM}$ tris[2carboxylethyl]phosphine in $25 \mathrm{mM}$ ammonium bicarbonate at $60{ }^{\circ} \mathrm{C}$ for $10 \mathrm{~min}$, followed by alkylation in $100 \mathrm{mM}$ iodoacetoamide $/ 25 \mathrm{~m} M$ ammonium bicarbonate at room temperature for $60 \mathrm{~min}$. After washing the alkylation buffer, the gel pieces were washed in $50 \%$ acetonitrile, followed by $100 \%$ acetonitrile. In-gel tryptic digestion was conducted by adding 100 ng of trypsin (Sequencing Grade Modified Trypsin; Promega, Madison, WI) in $10 \mu \mathrm{L}$ of $25 \mathrm{mM}$ ammonium bicarbonate. The gel pieces were allowed to swell, and an additional $25 \mu \mathrm{L}$ of $25 \mathrm{mM}$ ammonium bicarbonate was added to submerge the gel pieces. The digestion reaction was incubated at $30{ }^{\circ} \mathrm{C}$ for $16 \mathrm{hrs}$. Twenty-five microliters of $1 \%$ trifluoroacetic acid was added to stop the digestion reaction, and the tryptic peptides were extracted into $50 \%$ acetonitrile $/ 0.5 \%$ trifluoroacetic acid. The extract was evaporated by a SpeedVac concentrator (Thermo Electron Corporation, Waltham, MA). All water used was an ultra-pure grade. A Dionex UltiMate 3000 HPLC interfaced to an ABI Sciex QStar Elite Hybrid Quadrupole TOF mass spectrometer was used to analyze the tryptic digests by peptide mass fingerprinting. MASCOT (Matrix Science, Boston, MA) analysis of the MS/MS data against NCBInr 20100405 identified three candidates that show Probability Based MOWSE Score higher than $41(p<0.05)$; gi|6470150 (Homo sapiens BiP protein; MOWSE Score, 1202), gi|5729877 (Homo sapiens heat shock cognate $71 \mathrm{kDa}$ protein isoform 1; MOWSE Score, 1030), and gil292059 (Homo sapiens MTHSP75; MOWSE Score, 423).
Shotgun-mass spectrometry analysis

Aliquots of eluents from the SHetA2-microspheres and unconjugated microspheres were submitted for mass spectrometry analysis without electrophoresing them into gels. MS-grade solvents were from Burdick and Jackson, or Baker. Sequencing grade trypsin was from Promega. Other solutions were the highest grade available from Sigma-Aldrich. Samples were dissolved in $8 M$ urea, $100 \mathrm{~m} M$ Tris- $\mathrm{HCl} \mathrm{pH}=8.5$ at RT, $5 \mathrm{mM}$ tris(2-carboxyethyl)phosphine, and reduced at room temperature for $20 \mathrm{~min}$. After incubation, 1/20th volume of $200 \mathrm{mM}$ iodoacetamide was added. The alkylation was allowed to proceed for $15 \mathrm{~min}$ in the dark at room temperature, after which the samples were diluted with four volumes of $100 \mathrm{mM}$ Tris $\mathrm{HCl}$ $\mathrm{pH} 8.5$ and digested with $4 \mu \mathrm{g} / \mathrm{mL}$ trypsin overnight at $37{ }^{\circ} \mathrm{C}$. Digested samples were acidified with $1 \%$ formic acid, and purified by tip-based C18 chromatography (OMIX tips from Agilent). Samples were analyzed on a hybrid LTQ-OrbitrapXL mass spectrometer (Thermo Fisher Scientific) coupled to a New Objectives PV-550 nanoelectrospray ion source and an Eksigent NanoLC-2D chromatography system.

Peptides were analyzed by trapping on a $2.5 \mathrm{~cm}$ precolumn, followed by analytical separation on a $15-20 \mathrm{~cm}$ $75 \mu \mathrm{m}$ ID fused silica column, both packed with Magic C18 AQ (Bruker). Columns were terminated with an integral fused silica emitter prepared in house. Peptides were eluted using a $5-40 \%$ ACN $/ 0.1 \%$ formic acid gradient performed over $116 \mathrm{~min}$ at a flow rate of $250-300 \mathrm{~nL} / \mathrm{min}$. For each fullrange Fourier transform mass spectrometry (FT-MS) scan (nominal resolution of 60,000), the six most intense ions were analyzed via data-dependent MS/MS in the linear ion trap using dynamic exclusion for $150 \%$ of the observed chromatographic peak width. MS/MS settings used a trigger threshold of 8,000 counts, monoisotopic precursor selection (MIPS), and rejection of parent ions that had unassigned charge states or were previously identified as contaminants. Centroided ion masses were extracted using the extract_msn.exe utility from Bioworks 3.3.1 and were used for database searching with MASCOT v2.2.04 (Matrix Science) and X Tandem v2007.01.01.1 (www.thegpm.org).

Searches utilized a local database of human sequences, as well as sequences for 114 common adventitious laboratory contaminants. Trypsinolytic parent ions were searched with a parent ion tolerance of $10 \mathrm{ppm}$, and fragment ion masses were searched with a mass tolerance of $0.8 \mathrm{Da}$. Variable modifications included modification of cysteine by iodoacetamide or acrylamide, oxidation of methionine, N-terminal peptide cyclization via pyroglutamate or $S$-carbamoylmethylcysteine, and N-terminal protein modification by formylation or acetylation.

Scaffold (Version 3, Proteome Software Inc., Portland, OR) was used to validate MS/MS based peptide and protein identifications. Peptide identifications were accepted if they could be established at greater than $95 \%$ probability as specified by the 
Peptide Prophet algorithm [22]. Protein identifications were accepted if they could be established at greater than $99.0 \%$ probability and contained at least 2 identified peptides. Protein probabilities were assigned by the Protein Prophet algorithm [23]. Proteins that contained similar peptides and could not be differentiated based on MS/MS analysis alone were grouped to satisfy the principles of parsimony. A $t$-test was performed to determine significant differences in proteins identified in the eluents from SHetA2-microspheres in comparison to the eluents from unconjugated microspheres. $\mathrm{P}$ values of less than 0.05 were considered to be statistically significant.

\section{Cell culture and co-immunoprecipation experiments}

The A2780 human ovarian cancer cell line (gift of Michael Birrer, Harvard Medical School, Boston, MA) was cultured in RPMI 1640 tissue culture medium supplemented with $10 \%$ fetal bovine serum (FBS), antibiotic/antimycotic, $1 \mathrm{n} M$ sodium pyruvate and $1 \mathrm{~m} M$ HEPES buffer. Whole cell protein extracts were prepared from cultures treated with SHetA2 or DMSO for various times using M-PER Mammalian Protein Extraction Reagent (Thermo Scientific) or Triton $\times 100$ lysis buffer consisting of $1 \%$ Triton $\times 100,10 \mathrm{~m} M$ Tris $\mathrm{pH} 7.4$, $5 \mathrm{~m} M$ EDTA pH 8.0, and $50 \mathrm{~m} M \mathrm{NaCl}$. Cells were incubated and agitated by pipette or vortex every $5 \mathrm{~min}$ for $30 \mathrm{~min}$. After incubation, samples were spun down for $3 \mathrm{~min}$ at $10,000 \mathrm{~g}$ to remove debris. Cell lysates were centrifuged to remove debris for $5 \mathrm{~min}$ at 3,000 $\mathrm{g}$ using a 1:100 ratio of anti-p66shc antibody (Santa Cruz, Cat \# sc-967), anti-p53 antibody (Santa Cruz, Cat \# sc-126) or anti-mortalin antibody (Cell signaling Cat \# 3593) to lysate was added to each lysate immediately and incubated at $4{ }^{\circ} \mathrm{C}$ overnight. The next day, cells were incubated with Protein G-PLUS Agarose microspheres (Santa Cruz) for $1 \mathrm{hr}$. Microspheres were then washed 3 times with $1 \mathrm{~mL}$ of $10 \% \mathrm{NP}-40 /$ Tris $\mathrm{pH} 8.0$ buffer and centrifuged at 3, $000 \times \mathrm{g}$ for $4 \mathrm{~min}$. Twenty microliters of SDS loading buffer was then added to each sample, and the solution was boiled for $5 \mathrm{~min}$ before being electrophoresed into a $12-15 \%$ sodium dodecyl sulfate-polyacrylamide (SDS) gel electrophoresis, transferred to a polyvinylidene difluoride (PVDF) membrane, blocked in $5 \%$ milk for $1 \mathrm{hr}$ at room temperature, and then immunoblotted with the desired primary antibody (antimortalin antibody (Cell signaling Cat \# 3593), anti-p53 antibody (Santa Cruz, Cat \# sc-126) or anti-p66shc antibody (Santa Cruz, Cat \# sc-967) and then incubated overnight at $4{ }^{\circ} \mathrm{C}$. The membranes were then washed 3 times with $10 \mathrm{~mL}$ of PBS-Tween $20(0.1 \%)$, incubated with the appropriate HRP-conjugated secondary antibody for $30 \mathrm{~min}$ at room temperature and twashed 3 times with $10 \mathrm{~mL}$ of PBS-Tween $20(0.1 \%)$. Finally, specifically bound antibody was detected using Western Blotting Luminol Reagent (Santa Cruz Biotechnology) and exposure to X-Ray negative film.

\section{Results}

Identification of mortalin as an SHetA2-binding protein

To identify SHetA2 binding proteins, whole cell protein extracts isolated from the human A2780 ovarian cancer cell line were incubated with NanoLink Amino-Magnetic Microspheres conjugated to SHetA2. Unconjugated NanoLink Amino-Magnetic Microspheres microspheres were used as a control for non-specific binding. Solutions obtained through washing the microspheres and eluting with excess SHetA2 were evaluated on SDS-PAGE gels. Conditions were modified in 4 independent experiments to optimize the specificity and yield of proteins that bound to the SHetA2 microspheres (Table 1). In the second experiment, a band of approximately $75 \mathrm{kDa}$ was observed in the lane corresponding to the SHetA2 microsphere eluent and not in the lane corresponding to the unconjugated microsphere eluent in a silver-stained SDSPAGE gel (Fig. 2a). The amount of protein present in the gel however was insufficient for detection by the less-sensitive Coomassie blue stain or QTrap mass spectrometry. By increasing the microsphere to protein extract ratio and the number of washing steps, conditions were optimized to enable a sufficient amount of protein differentially bound to the SHetA2-microspheres compared to the unconjugated microspheres that could be detected in an SDS-gel stained with Coomassie blue (Fig. 2b). The areas of the dried gels for experiments 2 and 4 corresponding to the differential $75 \mathrm{kDa}$ band in the lanes corresponding to the SHetA2- and unconjugated microsphere eluents were excised and subjected to QStar mass spectrometry analysis. Although no proteins could be detected in the bands from experiment 2, three related heat shock protein A (HSPA) family members, HSPA5, HSPA8 and HSPA9/mortalin, were identified to be present in the band from the SHetA2-microspheres and not in the band from the unconjugated-microspheres from experiment 4 (Table 2).

To further validate the identification of these proteins, aliquots of the eluents from the SHetA2- and unconjugated microspheres from experiments 2 and 4 were evaluated by "Shotgun" Orbitrap Mass spectrometry analysis. Twenty-five individual proteins were identified to be present at significantly different levels in the SHetA2-microsphere eluent compared to the unconjugated-microsphere eluent in experiment 2 as determined by a $t$-test with $\mathrm{p}$ values below 0.05 being considered significant (Table 3). Among these proteins, all three HSPA5, HSPA8 and mortalin proteins, which were identified in the previous QStar analysis, also were found to be differentially present in the eluent from the SHetA2microspheres in comparison to the eluent from the unconjugated microspheres. Because experiment 4 had a much higher background of non-specifically bound proteins, it was not surprising that a much higher number (224) of individual 
Table 2 QStar Analysis of isolated $72 \mathrm{kDa}$ band of SHetA2 Binding Proteins

\begin{tabular}{|c|c|c|c|c|c|}
\hline Hit & $\begin{array}{l}\text { Accession } \\
\text { Number }\end{array}$ & $\begin{array}{l}\text { MOWSE } \\
\text { Score }\end{array}$ & Mass & $\begin{array}{l}\text { Avgerage } \\
\text { Intensity }\end{array}$ & Name: alias' \\
\hline 2 & gi|5729877 & 1030 & 71082.81 & 628.0486 & $\begin{array}{l}\text { HSPA8: Hsc70, 2410008N15Rik, Heat Shock Cognate 71-KDA, Heat } \\
\text { Shock Cognate 8, HS7C, HSC54, HSC71, HSC73, HSP/C70, HSP70, } \\
\text { HSP71, HSP73, Hsp 8, HSPA10, LAP1, MGC102007, MGC106514, } \\
\text { MGC114311, MGC118485, MGC128130, MGC131511, MGC29929, } \\
\text { NIP71 }\end{array}$ \\
\hline 3 & gi|292059 & 423 & 74019.46 & 409.2786 & $\begin{array}{l}\text { mortalin: Mortalin, Mitochondrial stress-70, Glucose Regulated Protein 75, } \\
\text { GRP-75, } 74 \text { kDa, CSA, Hsc74, Hsp74, Hsp74a, Mortalina, mortalinB, } \\
\text { MGC4500, MOT, Mot1, MOT2, Mthsp70, MTHSP75, PBP74, Stress-70 }\end{array}$ \\
\hline 1 & gi|6470150 & 1202 & 71002.07 & 312.8802 & $\begin{array}{l}\text { HSPA 5: Glucose Regulated Protein 78, GRP78, BiP, } 78 \text { kDa, AL022860, } \\
\text { AU019543, BIP, D2Wsu141e, D2Wsu17e, FLJ26106, HEAT SHOCK } \\
\text { 70KDA PROTEIN5, Hsce70, HSP70-5, Immunoglobulin heavy chain } \\
\text { binding, mBiP, MIF2, SEZ-7 }\end{array}$ \\
\hline
\end{tabular}

proteins, were identified to be differentially present by using the identical analysis procedure (Supplemental Table 1). Among these proteins, mortalin, (with a $p$ value of 0.00031 in Supplemental Table 1) was among the significant proteins in both experiments 2 and 4, while HSPA5 and HSPA 8 were found to be significant in experiment 2 , but had p-values slightly above 0.05 in experiment 4 (listed at the bottom of Supplemental Table 1). Thus, in two independent experiments evaluated by two different proteomics approaches, mortalin was identified to be specifically bound by SHetA2.

Table 3 Orbitrap analysis of SHetA2-microsphere eluent from experiment 2

\begin{tabular}{|c|c|c|c|c|}
\hline & Identified Protein & Accession \# & MS & $p$-value \\
\hline 1 & Heterogeneous nuclear ribonucleoprotein $\mathrm{G}$ & IPI00304692 & $42 \mathrm{kDa}$ & 0.00007 \\
\hline 2 & Uncharacterized protein & IPI01021093 (+4) & $33 \mathrm{kDa}$ & 0.00015 \\
\hline 3 & Endoplasmin & IPI00027230 & $92 \mathrm{kDa}$ & 0.00015 \\
\hline 4 & ATP synthase subunit beta, mitochondrial & IPI00303476 (+1) & $57 \mathrm{kDa}$ & 0.00063 \\
\hline 5 & Insulin-like growth factor 2 mRNA-binding protein 1 & IPI00008557 & $63 \mathrm{kDa}$ & 0.00078 \\
\hline 6 & $30 \mathrm{kDa}$ protein & IPI00964648 (+8) & $30 \mathrm{kDa}$ & 0.0015 \\
\hline 7 & Keratin, type I cytoskeletal 17 & IPI00450768 & $48 \mathrm{kDa}$ & 0.0033 \\
\hline 8 & Nucleolin & IPI00604620 & $77 \mathrm{kDa}$ & 0.0043 \\
\hline 9 & ATP synthase subunit alpha, mitochondrial & IPI00440493 & $60 \mathrm{kDa}$ & 0.0052 \\
\hline 10 & Isoform B1 of Heterogeneous nuclear ribonucleoproteins A2/B1 & IPI00396378 & $37 \mathrm{kDa}$ & 0.0061 \\
\hline 11 & $\begin{array}{l}\text { cDNA FLJ55072, highly similar to Succinate dehydrogenase } \\
\text { (ubiquinone) flavoprotein subunit, mitochondrial }\end{array}$ & IPI00964764 & $67 \mathrm{kDa}$ & 0.0065 \\
\hline 12 & Isoform 3 of Heterogeneous nuclear ribonucleoprotein $\mathrm{K}$ & IPI00807545 (+2) & $49 \mathrm{kDa}$ & 0.0072 \\
\hline 13 & Heat shock protein HSP 90-beta & IPI00414676 & $83 \mathrm{kDa}$ & 0.008 \\
\hline 14 & cDNA FLJ57283, highly similar to Actin, cytoplasmic 2 & IPI00930226 (+3) & $40 \mathrm{kDa}$ & 0.0084 \\
\hline 15 & Keratin, type I cytoskeletal 16 & IPI00217963 & $51 \mathrm{kDa}$ & 0.0092 \\
\hline 16 & Peroxiredoxin-1 & IPI00000874 (+1) & $22 \mathrm{kDa}$ & 0.016 \\
\hline 17 & X-ray repair cross-complementing protein 6 & IPI00644712 (+2) & $70 \mathrm{kDa}$ & 0.016 \\
\hline 18 & Glyceraldehyde-3-phosphate dehydrogenase & IPI00219018 (+2) & $36 \mathrm{kDa}$ & 0.016 \\
\hline 19 & Isoform 1 of Polyadenylate-binding protein 1 & IPI00008524 (+2) & $71 \mathrm{kDa}$ & 0.019 \\
\hline 20 & Putative cytochrome b-c1 complex subunit Rieske-like protein 1 & IPI00889196 (+1) & $31 \mathrm{kDa}$ & 0.019 \\
\hline 21 & Vimentin & IPI00418471 & $54 \mathrm{kDa}$ & 0.021 \\
\hline 22 & HSPA5/78 kDa glucose-regulated protein & IPI00003362 & $72 \mathrm{kDa}$ & 0.023 \\
\hline 23 & Isoform 2 of Heterogeneous nuclear ribonucleoprotein $\mathrm{A} / \mathrm{B}$ & IPI00334587 (+4) & $36 \mathrm{kDa}$ & 0.025 \\
\hline 24 & mortalin/Stress-70 protein, mitochondrial & IPI00007765 (+1) & $74 \mathrm{kDa}$ & 0.034 \\
\hline 25 & HSPA8/Isoform 1 of Heat shock cognate $71 \mathrm{kDa}$ protein & IPI00003865 (+1) & $71 \mathrm{kDa}$ & 0.042 \\
\hline
\end{tabular}




\section{Validation of SHetA2 effects on mortalin}

Mortalin is a molecular chaperone that binds client proteins and supports their functional configuration and intracellular localization [24]. To determine if SHetA2 interferes with mortalin binding to client proteins in situ, the ability of mortalin protein to be co-immunoprecipitated with its client proteins was evaluated in protein extracts from the A2780 and SK-OV-3 human ovarian cancer cell lines treated with SHetA2 or control solvent for 4 hrs. Western blot analysis of co-immunoprecipitates of protein extracts from both cell lines demonstrated that an antibody to the mortalin client protein called p66shc can pull down mortalin protein in the untreated controls, but not in the SHetA2-treated cultures, indicating that SHetA2 disrupted the interaction of these two proteins inside the cell (Fig. 3a). Another mortalin client protein, p53, was found to co-immunoprecipitate with the anti-mortalin specific antibody in untreated control A2780 cultures, but not in the SHetA2-treated cultures indicating that SHetA2 disrupts the interaction of these two proteins inside cells also (Fig. 3b). To further confirm SHetA2 disruption of this interaction, the A2780 protein extracts were coimmunoprecipitated with an anti-p53 specific antibody.
Western blot analysis confirmed that mortalin was coimmunoprecipitated with p53 in the control cultures, but not in the SHetA2-treated cultures (Fig. 3c). The SK-OV-3 cell line was not evaluated for mortalin/p53 interactions, because this cell line does not express p53. To verify that this effect was not due to a decrease in mortalin levels potentially caused by SHetA2 treatment, protein extracts from A2780 and SKOV-3 cultures treated with SHetA2 or control solvent over a range of treatment times were evaluated by Western blot, which demonstrated similar levels of mortalin regardless of the treatment time (Fig. 3d).

\section{Discussion}

This work has demonstrated that SHetA2 conjugated magnetic microspheres in concert with mass spectrometry approaches can be used to identify SHetA2 binding proteins. In our review of the literature to this date, there is no other report of using drug conjugated microspheres to identify a drug binding protein. The validity of the identified mortalin protein as a SHetA2-binding protein was supported by the identification of mortalin in two different approaches: QStar a
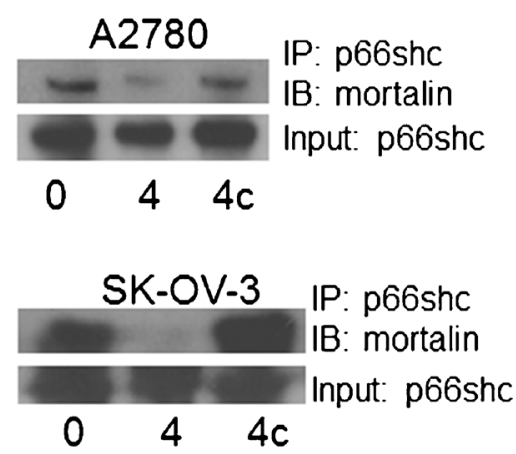

b

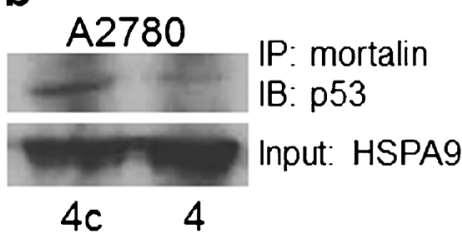

C

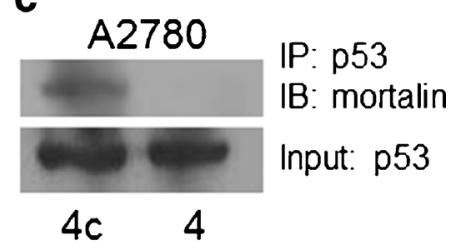

d

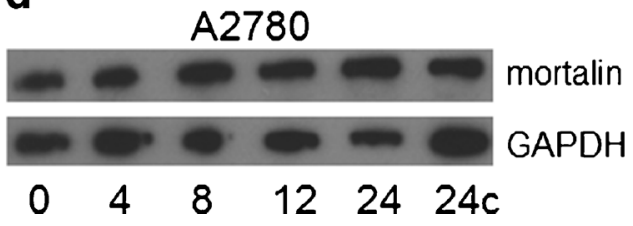

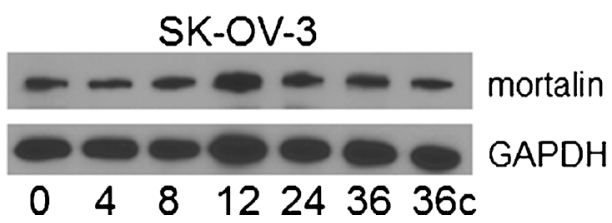

The experiment was performed as for A, except that the immunoprecipitation antibody used was against mortalin and the Western blot antibody used recognized $\mathrm{p} 53$. c, The experiment was performed as for A, except that the immunoprecipitation antibody use was against p53 and the Western blot antibody used recognized mortalin. d Western blot of protein extracts from A2780 and SK-OV-3 cells treated with $10 \mu M$ SHetA2 for the number of hours indicated at the bottom of the gel or treated with the same volume of DMS0 solvent for $24 \mathrm{hrs} \mathrm{(24c)}$ or $36 \mathrm{hrs}$ (36c). The blots were stripped and re-probed with an antibody that recognizes GAPDH as a protein loading control. These results are representative of at least three separate experiments. $I P=$ immunoprecipitating antibody, $I B=$ Immunoblotting antibody 
analysis of excised SDS-Gel bands and Orbitrap analysis of aliquots of the whole microsphere eluents. Although QStar analysis could not detect proteins in SDS-gel bands that were too low for visualization by Coomassie blue staining, the higher level of a non-specific unconjugated microsphere band present when the experiment was scaled up to a Coomassie blue-detectable level did not interfere with the ability of mortalin to be identified as being differentially present in the specific over the non-specific bands. Biological validation of mortalin was demonstrated by SHetA2 interference with mortalin binding to client proteins in human ovarian cancer cell lines.

Inhibition of mortalin is a likely mechanism of the SHetA2 effects on mitochondria and apoptosis in cancer cells. Within $30 \mathrm{~min}$ of treating cancer cells, SHetA2 induces mitochondrial swelling and loss of mitochondrial membrane potential, leading to release of cytochrome c, generation of reactive oxygen species (ROS) and activation of the intrinsic apoptosis pathway $[7,13,15,16,18$, $25,26]$. Although mortalin can be found in the endoplasmic reticulum (ER), cytoplasmic vesicles and cytosol, the majority of the protein present in the cell is located within mitochondria [24]. Maintenance of mitochondrial membrane potential needed for electron transport chain function and ATP generation is dependent on mortalin interaction with a protein called p66shc [27]. Release of p66shc from mortalin has been shown to cause opening of mitochondrial pores, release of cytochrome $\mathrm{c}$ and ROS generation [28]. Overexpression of mortalin can reduce ROS and protect against ischemic injury in vitro and in vivo [29]. Thus, we hypothesize that release of p66shc from mortalin repression mediates the mechanism by which SHetA2 induces intrinsic apoptosis. Current experiments are testing the validity of this hypothesis. Many of the other proteins identified in the two mass spectrometry approaches are known to be localized to the mitochondria and involved in metabolism. The fact that such proteins were identified in both approaches suggests that they may have attached indirectly to the magnetic microspheres through their affinity to mortalin attached to SHetA2.

SHetA2 disruption of mortalin binding to $\mathrm{p} 53$ is hypothesized to contribute to the mechanism by which SHetA2 regulates transcription factors and apoptosis. SHetA2 induces expression of the CHOP protein leading to enhancement of the death receptor extrinsic apoptosis pathway [10, 11, 30]. Mortalin binds to and sequesters p53 from translocating to the nucleus where it acts as a transcription factor to induce multiple genes that mediate apoptosis [31-33]. One of these p53induced transcription factors is the SHetA2-induced CHOP $[34,35]$. CHOP expression could also be altered as a result of indirect effects of SHetA2 releasing p66shc, thereby allowing it to interact with signal transducer and activator of transcription 3 (STAT3) and Forkhead Box O3A (FOXO3) [36-40], both of which regulate CHOP expression [41, 42]. Thus, we hypothesize that SHetA2-induced release of p53 from mortalin repression could augment SHetA2 mediated apoptosis. The ability of SHetA2 to induce apoptosis in p 53 null cell lines, such as SK-OV-3, suggests that SHetA2-induced release of $\mathrm{p} 53$ from mortalin repression can augment but is not required for SHetA2 apoptosis. The observation that mortalin binds and inhibits p53 induction of apoptosis in stressed cells, but not in weakly stressed or unstressed cells, could explain the differential induction of apoptosis by SHetA2 in cancer over normal cells [43].

Mortalin and SHetA2 also conflictingly regulate the Bcl-2 family of proteins. Upon activation, the pro-apoptotic Bax protein of this family undergoes a conformational change and migrates to the mitochondria where it forms a pore that allows release of cytochrome $\mathrm{c}$ and other pro-apoptotic factors. The anti-apoptotic Bcl-2 protein binds to Bax and prevents this pore formation. The ratio of $\mathrm{Bax}$ to $\mathrm{Bcl}-2$ has been shown to be a key determinant that can drive the initiation of apoptosis. SHetA2 reduces the expression of Bcl-2, but not Bax in cancer cells in vitro [7, 13, 26] and tumors in vivo[9] leading to induction of the intrinsic apoptosis pathway, while mortalin can prevent reduction of $\mathrm{Bcl}-2$ and conformational changes in Bax leading to inhibition of the intrinsic apoptosis pathway [44-46].

\section{Conclusions}

SHetA2 binding proteins, such as mortalin, can be identified by SHetA2-affinity chromatography combined with mass spectroscopic analysis leading to testable hypotheses regarding the SHetA2 molecular mechanism of action. SHetA2 interferes with mortalin binding to client proteins in ovarian cancer cells. Inhibition of mortalin interaction with client proteins represents a logical mechanism for SHetA2-induced apoptosis, a theory that will be tested in future studies.

Acknowledgments The research was supported by an Oklahoma State University grant for Technology Business Assessment Group Grant (KDB/RAB), a University of Oklahoma Health Sciences Center Vice President for Research Bridge Grant (DMB, AL), a Stephenson Cancer Center Gynecologic Cancer Program Grant (DMB, AL) and by the NIH EY017888 Grant (HM, AS). The QStar mass spectrometry analysis was performed by the Mass Spectrometry and Proteomics Facility at the University of Oklahoma Health Sciences Center. The Orbitrap mass spectrometry analyses were performed in the DNA/Protein Resource Facility at Oklahoma State University, using resources supported by the NSF MRI and EPSCoR programs (DBI/0722494). We thank Elangovan Thavathiru (University of Oklahoma Health Sciences Center) for technical assistance in working out the parameters for co-immunoprecipitation analysis.

Competing Interests The authors declare that they have no competing interests. 
Open Access This article is distributed under the terms of the Creative Commons Attribution License which permits any use, distribution, and reproduction in any medium, provided the original author(s) and the source are credited.

\section{References}

1. Zhang Y, Hua Y, Benbrook DM, Covey JM, Dai G, Liu Z, Chan KK (2006) High performance liquid chromatographic analysis and preclinical pharmacokinetics of the heteroarotinoid antitumor agent, SHetA2. Cancer Chemother Pharmacol 58:561-569. doi:10.1007/ s00280-006-0211-Z

2. Liu Z, Zhang Y, Hua YF, Covey JM, Benbrook DM, Chan KK (2008) Metabolism of a sulfur-containing heteroarotionoid antitumor agent, SHetA2, using liquid chromatography/tandem mass spectrometry. Rap Comm Mass Spec 22:3371-3381. doi:10.1002/rcm.3744

3. Mic FA, Molotkov A, Benbrook DM, Duester G (2003) Retinoid activation of retinoic acid receptor but not retinoid $\mathrm{X}$ receptor is sufficient to rescue lethal defect in retinoic acid synthesis. PNAS USA 100:7135-7140. doi:10.1073/pnas.1231422100

4. Doppalapudi RS, Riccio ES, Davis Z, Menda S, Wang A, Du N, Green C, Kopelovich L, Rao CV, Benbrook DM, Kapetanovic IM (2012) Genotoxicity of the cancer chemopreventive drug candidates CP-31398, SHetA2, and phospho-ibuprofen. Mutat Res 746:78-88. doi:10.1016/j.mrgentox.2012.03.009

5. Kabirov KK, Kapetanovic IM, Benbrook DM, Dinger N, Mankovskaya I, Zakharov A, Detrisac C, Pereira M, Martín-Jiménez T, Onua E, Banerjee A, van Breemen RB, Nikolić D, Chen L, Lyubimov AV (2012) Oral toxicity and pharmacokinetic studies of SHetA2, a new chemopreventive agent, in rats and dogs. Drug Chem Toxicol 36:284-295. doi:10.3109/01480545.2012.710632

6. Benbrook DM, Kamelle S, Guruswamy S, Lightfoot S, Rutledge T, Gould N, Hannafon B, Dunn ST, Berlin KD (2005) Flexible heteroarotinoids (Flex-Hets) exhibit improved therapeutic ratios as anti-cancer agents over retinoic acid receptor agonists. Inv New Drugs 23:417-428. doi:10.1007/s10637-005-2901-5

7. Liu T, Masamha CP, Chengedza S, Berlin KD, Lightfoot S, He F, Benbrook DM (2009) Development of flexible-heteroarotinoids for kidney cancer. Mol Cancer Ther 8(5):1227-1238. doi:10.1158/15357163.MCT-08-1069

8. Naylor M, Thompson DM, Lightfoot S, Benbrook DM (2013) Anticancer activities and interaction of imiquimod and Flex-Het, SHetA2, in melanoma and ovarian cancer. J Cancer Ther 4:7-19. doi:10.4236/ jct.2013.46A1002

9. Benbrook DM, Guruswamy S, Wang Y, Sun Z, Mohammed A, Zhang Y, Li Q, Rao CV (2013) Chemoprevention of colon and small intestinal tumorigenesis in APCmin/+ Mice By SHetA2 (NSC721689) without toxicity. Cancer Prev Res 6:908-916. doi: 10.1158/1940-6207.capr-13-0171

10. Moxley KC, Chengedza S, Benbrook DM (2009) Induction of death receptor ligand-mediated apoptosis in epithelial ovarian carcinoma: the search for sensitizing agents. Gyn Onc 115:438-442. doi:10. 1016/j.ygyno.2009.09.007

11. Chengedza S, Benbrook DM (2010) NF-kB is involved in SHetA2 circumvention of TNF-a resistance, but not induction of intrinsic apoptosis. Anti-Cancer Drugs 21:297-305. doi:10.1097/CAD. 0b013e3283350e43

12. Masamha CP, Benbrook DM (2009) Cyclin D1 degradation is sufficient to induce $\mathrm{G} 1$ cell cycle arrest despite constitutive expression of cyclin E2 in ovarian cancer cells. Cancer Res 69:6565-6572. doi:10. 1158/0008-5472.CAN-09-0913

13. Liu T-Z, Hannafon B, Gill L, Kelly B, Benbrook DM (2007) FlexHets differentially induce apoptosis in cancer over normal cells by directly targeting mitochondria. Mol Cancer Ther 6:1814-1822. doi: 10.1158/1535-7163.MCT-06-0279

14. Long A, Masamha CP, Zhao D, Benbrook DM (2013) Differential roles of autophagy in ovarian cancer and healthy cells in response to SHetA2 Drug. Cell Death Dis:publication pending review of revision

15. Chun K-H, Benbrook DM, Berlin KD, Hong WK, Lotan R (2003) Induction of apoptosis in head and neck squamous cell carcinoma (HNSCC) cell lines by heteroarotinoids through a mitochondrial dependent pathway. Cancer Res 63:3826-3832, http://cancerres. aacrjournals.org/content/63/13/3826.abstract

16. Liu S, Brown CW, Berlin KD, Dhar A, Guruswamy S, Brown D, Gardner GJ, Birrer MJ, Benbrook DM (2004) Synthesis of flexible sulfur-containing heteroarotinoids that induce apoptosis and reactive oxygen species with discrimination between malignant and benign cells. J Med Chem 47:999-1007. doi:10.1021/jm030346v

17. Benbrook DM, Madler MM, Spruce LW, Birckbichler PJ, Nelson EC, Subramanian S, Weerasekare GM, Gale JB, Patterson MK Jr, Wang B, Wang W, Lu S, Rowland TC, DiSilvestro P, Lindamood C III, Hill DL, Berlin KD (1997) Biologically active heteroarotinoids exhibit anticancer activity and decreased toxicity. J Med Chem 40: 3567-3583

18. Guruswamy S, Lightfoot S, Gold M, Hassan R, Berlin KD, Ivey RT, Benbrook DM (2001) Effects of retinoids on cancerous phenotype and apoptosis in organotypic culture of ovarian carcinoma. J Nat Cancer Inst 93:516-525. doi:10.1093/jnci/93.7.516

19. Ziegler S, Pries V, Hedberg C, Waldmann H (2013) Target identification for small bioactive molecules: finding the needle in the haystack. Angew Chemie Int Ed 52:2744-2792. doi:10.1002/anie. 201208749

20. Lomenick B, Olsen RW, Huang J (2010) Identification of direct protein targets of small molecules. ACS Chem Biol 6(1):34-46. doi:10.1021/cb100294v

21. Nammalwar B, Bunce RA, Benbrook DM, Lu T, Li H-F, Chen Y-D, Berlin KD (2011) Synthesis of N-[3,4-dihydro-4-(acetoxymethyl)-2, 2,4-trimethyl-2H-1-benzothiopyran-6-yl]-N'-(4-nitrophenyl)thiourea and $\mathrm{N}$-[3,4-dihydro-4-(hydroxymethyl)-2,2,4-trimethyl-2H-1benzothiopyran-6-yl]-N'-(4-nitrophenyl)thiourea, a major metabolite of N-(3,4-Dihydro-2,2,4,4-tetramethyl-2H-1-benzothiopyran-6-yl)N'-(4-nitrophenyl)thiourea. Phosphorus Sulfur Silicon Rel Elem 186:189-204. doi:10.1080/10426507.2010.534521

22. Keller A, Nesvizhskii AI, Kolker E, Aebersold R (2002) Empirical statistical model to estimate the accuracy of peptide identifications made by MS/MS and database search. Anal Chem 74:5383-5392. doi:10.1021/ac025747h

23. Nesvizhskii AI, Keller A, Kolker E, Aebersold R (2003) A statistical model for identifying proteins by tandem mass spectrometry. Anal Chem 75:4646-4658. doi:10.1021/ac0341261

24. Londono C, Osorio C, Gama V, Alzate O (2012) Mortalin, apoptosis, and neurodegeneration. Biomol 2:143-164. doi:10.3390/ biom 2010143

25. Benbrook DM (2002) Refining retinoids with heteroatoms. Minirev Med Chem 2:271-277. doi:10.2174/1389557023406160

26. Lin Y, Liu X, Yue P, Benbrook DM, Berlin KD, Khuri FR, Sun S-Y (2008) Involvement of c-FLIP and survivin down-regulation in flexible heteroarotinoid-induced apoptosis and enhancement of TRAILinitiated apoptosis in lung cancer cells. Mol Cancer Ther 7:35563565. doi:10.1158/1535-7163.MCT-08-0648

27. Deocaris CC, Kaul SC, Wadhwa R (2006) On the brotherhood of the mitochondrial chaperones mortalin and heat shock protein 60. Cell Stress Chap 11:116-128. doi:10.1379/CSC-144R.1

28. Orsini F, Migliaccio E, Moroni M, Contursi C, Raker VA, Piccini D, Martin-Padura I, Pelliccia G, Trinei M, Bono M, Puri C, Tacchetti C, Ferrini M, Mannucci R, Nicoletti I, Lanfrancone L, Giorgio M, Pelicci PG (2004) The life span determinant p66Shc localizes to mitochondria where it associates with mitochondrial heat shock 
protein 70 and regulates trans-membrane potential. J Biol Chem 279: 25689-25695. doi:10.1074/jbc.M401844200

29. Xu L, Voloboueva LA, Ouyang Y, Emery JF, Giffard RG (2008) Overexpression of mitochondrial Hsp70/Hsp75 in rat brain protects mitochondria, reduces oxidative stress, and protects from focal ischemia. J Cereb Blood Flow Metab 29:365-374

30. Lin Y-D, Chen S, Yue P, Zou W, Benbrook DM, Liu S, Le TC, Berlin KD, Khuri FR, Sun S-Y (2008) CAAT/enhancer binding protein homologous protein-dependent death receptor 5 induction is a major component of SHetA2-induced apoptosis in lung cancer cells. Cancer Res 68(13):5335-5344. doi:10.1038/jcbfm.2008.125

31. Gestl EE, Anne Bottger S (2012) Cytoplasmic sequestration of the tumor suppressor p53 by a heat shock protein 70 family member, mortalin, in human colorectal adenocarcinoma cell lines. Biochem Biophys Res Comm 423:411-416. doi:10.1016/j.bbrc.2012.05.139

32. Grover A, Priyandoko D, Gao R, Shandilya A, Widodo N, Bisaria VS, Kaul SC, Wadhwa R, Sundar D (2012) Withanone binds to mortalin and abrogates mortalin-p53 complex: computational and experimental evidence. Int J Biochem Cell Biol 44:496-504. doi: 10.1016/j.biocel.2011.11.021

33. Lu WJ, Lee NP, Kaul SC, Lan F, Poon RT, Wadhwa R, Luk JM (2011) Induction of mutant p53-dependent apoptosis in human hepatocellular carcinoma by targeting stress protein mortalin. Int J Cancer 129:1806-1814. doi:10.1002/ijc.25857

34. Liu T, Laurell C, Selivanova G, Lundeberg J, Nilsson P, Wiman K (2007) Hypoxia induces p53-dependent transactivation and Fas/ CD95-dependent apoptosis. Cell Death Differ 14:411-421. doi:10. 1038/sj.cdd.4402022

35. Su Z, Lebedeva I, Sarka RD, Gopalkrishnan R, Sauane M, Sigmon C, Yacoub A, Valerie K, Dent P, Fisher P (2003) Melanoma differentiation associated gene-7, mda-7/IL-24, selectively induces growth suppression, apoptosis and radiosensitization in malignant gliomas in a p53-independent manner. Oncogene 22:1164-1180. doi:10. 1038/sj.onc. 1206062

36. Skolnik E, Lee C, Batzer A, Vicentini L, Zhou M, Daly R, Myers M, Backer J, Ullrich A, White M (1993) The SH2/SH3 domain-containing protein GRB2 interacts with tyrosine-phosphorylated IRS1 and Shc: implications for insulin control of ras signalling. EMBO J 12:19291936, http://www.ncbi.nlm.nih.gov/pmc/articles/PMC413414/

37. VanderKuur J, Allevato G, Billestrup N, Norstedt G, Carter-Su C (1995) Growth hormone-promoted tyrosyl phosphorylation of SHC proteins and SHC association with Grb2. J Biol Chem 270:75877593. doi: $10.1074 / j b c .270 .13 .7587$
38. Smit L, de Vries-Smits A, Bos J, Borst J (1994) B cell antigen receptor stimulation induces formation of a Shc-Grb2 complex containing multiple tyrosine-phosphorylated proteins. J Biol Chem 269:20209-20212, http://www.jbc.org/content/269/32/ 20209.long

39. Nemoto S, Finkel T (2002) Redox regulation of forkhead proteins through a p66shc-dependent signaling pathway. Science 295:2450 2452. doi:10.1126/science. 1069004

40. Hu Y, Wang X, Zeng L, Cai D, Sabapathy K, Goff S, Firpo E, Li B (2005) ERK phosphorylates p66shcA on Ser36 and subsequently regulates p27kip1 expression via the Akt-FOXO3a pathway: implication of p27kip1 in cell response to oxidative stress. Mol Biol Cell 16:3705-3718. doi:10.1091/mbc.E05-040301

41. Timofeeva O, Tarasova N, Zhang X, Chasovskikh S, Cheema A, Wang H, Brown M, Dritschilo A (2013) STAT3 suppresses transcription of proapoptotic genes in cancer cells with the involvement of its N-terminal domain. PNAS USA 110:1267-1272. doi:10.1073/pnas. 1211805110

42. Greer E, Oskoui P, Banko M, Maniar J, Gygi M, Gygi S, Brunet A (2007) The energy sensor AMP-activated protein kinase directly regulates the mammalian FOXO3 transcription factor. J Biol Chem 282:30107-30119. doi:10.1074/jbc.M705325200

43. Lu WJ, Lee NP, Kaul SC, Lan F, Poon RTP, Wadhwa R, Luk JM (2011) Mortalin-p53 interaction in cancer cells is stress dependent and constitutes a selective target for cancer therapy. Cell Death Differ 18(6):1046-1056. doi:10.1038/cdd.2010.177

44. Yang L, Liu X, Hao J, Yang Y, Zhao M, Zuo J, Liu W (2008) Glucose-regulated protein 75 suppresses apoptosis induced by glucose deprivation in PC12 cells through inhibition of Bax conformational change. Acta Biochimet Biophys Sin 40:339-348. doi:10. 1111/j.1745-7270.2008.00409.x

45. Qu M, Zhou Z, Chen C, Li M, Pei L, Yang J, Wang Y, Li L, Liu C, Zhang G, Yu Z, Wang D (2012) Inhibition of mitochondrial permeability transition pore opening is involved in the protective effects of mortalin overexpression against beta-amyloid-induced apoptosis in SH-SY5Y cells. Neurosci Res 72:94-102. doi:10.1016/j.neures. 2011.09.009

46. Yang L, Guo W, Zhang Q, Li H, Liu X, Yang Y, Zuo J, Liu W (2011) Crosstalk between Raf/MEK/ERK and PI3K/AKT in suppression of Bax conformational change by Grp75 under glucose deprivation conditions. J Mol Biol 414:654-666. doi: 10.1016/j.jmb.2011.09.009 